\title{
Difficult Dialogue: A tool towards racial harmony in a multicultural church
}

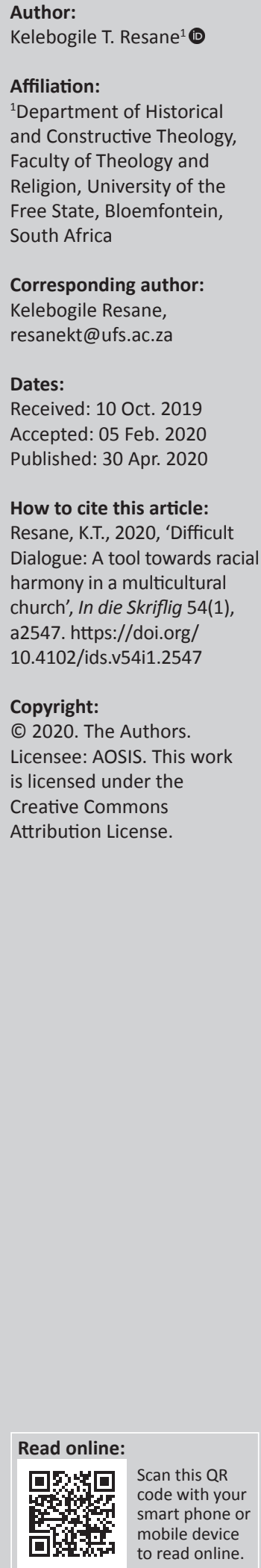

This article is aiming to promote a learning programme known as Difficult Dialogue. This programme is used in universities and colleges across the world to forge interaction, dialogue and transparency where people divided by race, religion, gender or disabilities come together to dialogue as a way of understanding each other. The programme can be used in pursuit of building a multicultural church that can truly demonstrate that the church is ONE and agrees with the biblical teaching about unity of the believers. There are three reasons expounded why leading the multicultural church in South Africa seems to be a challenge. Firstly, people from the culture of segregation are generally scared or reserved of different cultures. The cultural gaps are too wide to close. Secondly, many who desire to lead multicultural churches continue to live mono-ethnic lives; and finally, the difficulty is exacerbated by a misnomer of those who desire to lead multicultural churches confusing to have people of colour present in the church being a multicultural church. The solution to this is three-pronged, as there are three practical suggestions towards a multicultural church's engagement through Difficult Dialogue. The first suggestion calls for a change of a church space into a centre of learning; secondly, to utilise people's stories; and finally, to strive for a church culture that reflects multiculturalism and diversity.

Keywords: Difficult Dialogue; multiculturalism; church; culture; South Africa.

\section{As a matter of introduction}

Difficult Dialogue is a learning programme that became popular in North American universities in the past three decades or so. It is a learning method applied in both multicultural and a multireligious class. Broadly speaking, the uttermost aim of a dialogue is to understand another person's views and beliefs better. Dialogue does not seek consensus or to convince another of a specific viewpoint. Dialogue means 'finding meaning through words'. It is an encounter with those who might have different opinions, values and beliefs to one's own. It is the process by which one understands the other person's values and beliefs better. In the same way, the other person starts to understand me. Moon (2013:179) defines dialogue as building 'on the common ground between members of historically adversarial groups to help overcome vicious cycles of retaliation.'

There is a rallying call that churches should join broader communities in ensuring that churches themselves remain places where freedom of expression and faith are protected and embraced. Churches should become platforms on which multiculturalism is celebrated through Difficult Dialogue. This should be prioritised as a church's missional focus. Difficult Dialogue is an inevitable and pragmatic necessity, because daily life constitutes complex relations among ideological, economic, historical, material, discursive and affective articulations (Kanpol \& McLaren 1995:8). Religion is not excluded, and the ecclesiastical mandate is calling people into a communion where relationships are forged by horizontal and vertical communication, which is relationally God-human and human-human interaction. The South African church is caught between the rock and face, especially in the urban and suburban areas. As the instrument of God to bring peace in the world, the church should know that one of its tasks in the city 'as an adaptive mechanism is to assist in the social integration of the various ethnic groups in a multiracial society' (Shorter 1991:81).

A multicultural church is beyond multiracial composition. It is multicultural, because it has diverse cultures in its membership and composition. Post-apartheid South Africa experiences a high influx of people from other parts of Africa and other continents, especially Asia. These migrants are part of the South African society, and the church remains with a pivotal role to assimilate these into a host society. In this article, the focus is on a multicultural church that is basically made of South Africans coming from different cultures and had experienced the demon of separateness for 
decades. These are the people who carry some scars of racial bigotries that now must learn to live and worship God together.

\section{Difficult Dialogue in a multicultural church}

No topics contain such explosive response in the church gatherings as councils, synods, conferences, et cetera, than those involved in diversity issues. Be it about sexism (heterosexist, orientation, etc.), racism, multiculturalism or even physical disability, Difficult Dialogues call for the church leadership and theologians to intervene, initiate and moderate. When the white church supremacists converge at the denominational conferences, councils or synods with resistance to coalition of cultures in their churches, there is the antithesis of heaven. Despite these anomalies, the reality and inevitability are inescapable that 'Diversity across populations, including demographics of age, gender, race, and region were significant factors that qualitatively changed religious trajectories' (Francis 2019:503). The historical Afrikaans churches such as the Reformed family churches (Dutch Reformed Church, Dutch Reformed Church of Africa, Reformed Churches in South Africa), the two classical Afrikaans Pentecostal churches (Apostolic Faith Mission; Full Gospel Church of God), and some few smaller Afrikaans church groups are the ones struggling towards multiculturalism. Some evangelical groups such as the Baptist Union also strive towards the multicultural composition of their churches. The historical mainline churches such as the Roman Catholic, Anglicans, Methodists and others are multiracial in many aspects. The former groups are indeed on the brink of a great explosive catastrophe.

The rationale behind these potential explosions lies in the fact that these issues are heavily laden with values and emotion for church members and the clergy. They have become hot potatoes to be discarded due to their potentials for encroaching into people's comfort zones. A discourse on these points without some measure of personal investment can be difficult. Furthermore, many South Africans in one way or another should face these oppressive forces, as it is impossible for any individual not to possess strong ideas and a personal interest on these issues. Regardless of this current scenario of people coiling back into the cocoon, the reality is right on our face as Resane (2019a) says:

Multiculturalism is a dynamic process within the evolving cultures. It is a massive challenge for South African demographic dynamics due to our history of racial compartmentalisation. (p. 24)

Managing these kinds of conversations in the church for some, needs some form of a critical skill. 'Running a multiethnic urban parish calls for considerable tact and skill' (Shorter 1991:81-82). If we do not allow or encourage such conversations in our churches, we send the message of support that these ideas and concerns are appropriate for our missional calling and tasks, contrasting the fact that ours is the church liberated from the shackles of apartheid and all its by-products. Church leaders, just like school-teachers, need to be able to recognise and be equipped to facilitate race talk discussions in a productive manner (Sue 2015:230). Church leaders and the academics are uniquely positioned to address the lack of racial awareness just as much as they are the participants of forums that facilitate debate in safe spaces to examine doctrines and ecclesial practices (Fears 2017:19).

There is no doubt that understanding and appreciating diversity requires the whole church to come to grips with its historical contradictory association with the repressive system of apartheid. In many ways, the historically marginalised church members are theologically similar to other church members, as they are also and at the same rhythm carriers of imago Dei. Churches on the way towards multiculturalism have many more unique needs, for example how to lead and manage them as theological or pastoral trainings, never equipped or prepared incumbent pastors on how to lead these kinds of churches (Clapp 1996:94).

One of the reasons for the difficulty of a multiracial church in South Africa, is that as victims of apartheid, we are scared or reserved of different cultures. Our cultures always carry different expectations, and these overflow into the church, for example the music styles and food choices. Through Difficult Dialogue, the church can help people of other cultures by enhancing a sense of shared identity and cultural inclusiveness. This is a key part of the adaptability necessary for a multiracial congregation to succeed. As they strive for inclusiveness, leaders aspiring for multiracial churches inevitably sense some forsakenness by their leaders who fail to avail themselves as role models. They might even face opposition from their own circles. A Dutch Reformed Church in a historically white suburb may choose to close or sell the building instead of opening it for a multiracial congregation. The pastor might desire to have a multiracial congregation, but the council may oppose the idea.

Another difficulty for a multiracial church is that many who desire to lead multicultural churches continue to live monoethnic lives. The legacy of apartheid is in their blood. They consult their white counterparts on how to go about starting or leading a multicultural church. This is a clear revelation that they do not have many relationships of trust with people of colour. Becoming a multicultural church is not offering a soup kitchen, running a food bank, or changing a programme, but it is a whole life change. If your life is not multi- or crosscultural, it will be difficult and potentially damaging to try to lead a church to be multicultural.

Sociologists such as Emerson (2000) define a multi-ethnic church as a church with a minimum of $20 \%$ of members who do not identify with the dominant racial group. I would apply the same rule to the life of the pastor. If a minimum of $20 \%$ of a pastor's personal relationships do not consist of people of another racial group, he is unable to effectively lead a multi-ethnic church. Please note that not every multiracial group is truly multicultural. The kind of multicultural 
community, which I am envisioning in this article, is one that represents not just various racial groups or colours, but also various cultures coming together under the banner of Jesus Christ.

The other difficulty for churches in South Africa to become multicultural is that many who desire to lead multicultural churches continue to listen to mono-cultural voices. Effectively leading a multicultural church involves both diverse relationships and leaders prepared to listen to diverse voices. This can be much more difficult than it sounds when all of one's theological education and ministry training have come from a monolithic background. We often confuse our cultural understanding of theology with truly biblical theology, and thus we are unable to honour the perspectives of those with a different cultural lens.

A pastor cannot have a healthy multicultural church when he primarily listens to mono-cultural voices. To a pastor, a healthy multicultural church, the leadership structure and team should reflect the demographics of the church. The leadership team must share equal authority with each member willing not only to listen, but also to submit to different perspectives on how to apply their shared theology to real life. 'If possible, the pastoral team itself should cater for several vernaculars' (Shorter 1991:81).

Finally, a difficulty for multicultural churches in South Africa is exacerbated by a misnomer of those who desire to lead multicultural churches confusing to have people of colour present in the church being a multicultural church. Some evangelical leaders misunderstand the essence of a multicultural church by declaring that theirs are the churches led and motioned by the Holy Spirit towards the multiculturalism they now possess. They declare that they never set out to have a multicultural church, yet God has granted it to them. My conviction is that a maturing multicultural church is not just a gathering of people of different skin colours or cultures convening in the same building once a week. A maturing multicultural church is a family of people of different cultures, learning to confront and destroy barriers that the worldly ideologies has placed between them. Confidence and transparency must be a locus of the multicultural church whereby people walk together in the light with each other. It is genuinely true that ' $[w]$ hen genuine dialogue occurs, people feel transformed, spoken to, understood' (Moon 2013:197). This requires some acknowledgement of diverse and unique experiences and challenges of multifaceted groups in the church. This way, the church becomes a real communio ecclesia that cares for each other. The price to pay here is the active engagement with Difficult Dialogues.

Acts $6: 1-7$ is an important text to consider. Hearing of the conflict in the church whereby one cultural group felt compromised, the strategy devised was the appointment of seven Spirit-filled men to ensure its needs were no longer neglected. A pastor should intentionally pursue and care for the unique needs of a multicultural congregation to avoid imposing his own cultural preferences and values.
This does not mean people of differing skin tones will never attend, but it does guarantee that those attending will compromise their feelings or learn to live with pain of being marginalised. Unfortunately, this will deny the church the opportunity to know and to learn from other cultures, and marvel at the incomparable power of Christ to authentically unite people and cultures who appear divided. Therefore, failure to build multicultural churches through Difficult Dialogue, employing a thoughtful intentionality, may become fruitless efforts.

Life in South Africa is deeply shaped by racial segregation. Many South African citizens grow up in segregation. Until 1994, segregation was significant in schools, workplaces, entertainment, social gatherings, places of worship and neighbourhoods. Amazingly and shamefully, all spaces are transforming at an alarming rate, except in places of worship. Churches are the most racially segregated spaces than the secular spaces. Very few churches are becoming multiracial in composition. Those that claim multicultural composition are mostly the historically white turning black. This is influenced by the demographic dynamics. One unfortunate tendency is multiculturisation that comes by some form of imperial coercion. The white Christians are shouting from the tall hidden walls to their black neighbours to jump over the walls and join them in their churches. The walls of hostilities created by the prejudices and imbalances of the past, are not broken down for feasible cross-cultural church composition. For black Christians, there is no attempt to invite the whites to join their ranks of worship. The obvious reason for this is that it has proved impossible for white people to be led by black people in spaces of religious expressions. If there is something that white people in South Africa are not prepared to give away, it is their spaces of worship, including styles of worship, confessions, and sometimes even a liturgy. The conservative white Dutch Reformed Christian, for instance finds it difficult to be part of the non-racial Uniting Reformed Church where the Belhar Confession is part of the liturgy. This is necessitated by the white believers' notion, that this confession is communistic. White people have no option to be politically led by black people, but ecclesiastically it is a big NO. My Afrikaner Reformed friend in Mafikeng told me many years ago that Afrikaners had lost everything - land, government, self-identity, et cetera, but are left with the church as the one and only thing. And they are not willing to give it away. They will fight for it until the last man!

Therefore, the big question in church remains whether there is a real concept of multicultural church in the post-apartheid South Africa. If it happens, it becomes very superficial where one cultural group is subjected to a specific leniency of worship such as the type of music, confessions, et cetera. In many quarters, the church retreats to a cocoon lifestyle of glossing over the real issues that need some dialogical deliberations. The church resorts to eschatological euphoria of focusing only on new life in Christ and a bliss that awaits believers in heaven. Soteriology and eschatology are the two doctrines that are variously used to butter up the real issues of life. 


\section{Church and Difficult Dialogue}

Dealing with shocking events such as racial attacks, xenophobic attacks, gender-based violence and more is challenging in any church environment. Church leaders are recommended that they become familiar with the concept of Difficult Dialogue in order to engage with communities for better understanding of the communities engaged. For most pastors in South Africa, leading church discussion on difficult topics is an emotive issue. This is exacerbated by the fact that we never fully know which issues will be 'hot buttons' for our congregants. Conversations can go off tangent, leading towards the church careening out of control. This article seeks to help church leaders feel more confident leading Difficult Dialogues by encouraging reflection on how such discussions connect with larger faith issues. An attempt is made to provide specific strategies and resources that church leaders can use to create more productive conversations in their churches.

A church in a democratic society should strive towards innovative practices that promote respectful, transformative dialogue on controversial topics, and complex social order to foster faith and Christian praxis. Post-apartheid teaching, preaching and applying Christian faith that engages in civil discourse on controversial topics such as racism, sexuality, and disability must become an integral component of the missions of churches and families across the country. Shorter (1991) puts it in a nutshell:

One of the Church's urban tasks, therefore, is to break down the inner frontiers that divide and exclude people. This is not done by denying the validity of ethnic cultures, but by cultural reeducation, cultural development and especially intercultural communication within the parish. The aim is to convert cultural pluralism into genuine multiculturalism. It is not enough for ethnic cultures to be juxtaposed in close proximity (cultural pluralism). There must be a communication between them. They should co-exist in a state of complementarity (multiculturalism). From experiencing other cultures with a certain degree of shock, people are led to co-operate in spite of the differences they experience. While there may be a measure of cultural loss, nevertheless cultural identities are maintained through dialogue and cultural interchange. This can even result in a measure of cultural enrichment. (p. 81)

Like citizens across the country, church leaders are concerned about the increasingly polarised and hostile nature of public discourse within our democracy. It is unfortunate that intolerance perpetuated by either political opinions, or personal identities that characterise the national conversation. In addition, faith communities have increasingly experienced restrictions on transparency, freedom of speech and the expression of controversial views by both pastors and congregants. Pastors are aware of the importance of engagement in civic and political discourses. They recognise that religious freedom and the expression of controversial views are at the core of a church's mission, and that churches are among the few places where members can experience and develop these capacities and freedoms.
Historically, the South African church is recovering from a high-stress situation. So often, it finds itself emotionally ill-prepared to have the conversation desperately needed as a journey to recovery. Humanly, conversations dominated by a lot of emotion or a lot of baggage of the past, tends to be unjustifiably critical, and successfully more difficult to engage. It is natural for people to want to avoid conversation with people they have a conflict with, because these people have somehow betrayed our trust. This is the reason the racial tension in South Africa is still very intense. The gap between each other is very wide. Those on the opposite side do not meet our expectations. We do not yet know them, and they do not know us. Inevitably the two opposite sides shut themselves down inside. In the situation, the pastor who leads should make sure he has effective communication skills that are vital to success in life, but even more so when the stakes are high.

The church, which is recovering from some psychological victimisation due to racism, should involve itself in Difficult Dialogue that encourages speaking for oneself, respectfully and from personal experience. Walking together in the light is the key issue and a driving force. It is a matter of listening for what one wants to understand better versus for what one wants to debate. In the process it is reflecting on one's own experiences and perspectives, which leads to an inquiry into the experiences and perspectives of others. Therefore, Difficult Dialogue in a church setting engages speaking, listening, reflecting and enquiring.

Applying Difficult Dialogue in a church setting embraces the following principle: There is No Them, there is Just Us. This principle encourages the flow of conversation whereby participants listen with all their attention; and suspend certainty. This means participants do not let what they know get the best of them. Importantly, the participants are encouraged to engage in conversation whereby they hold the space for difference. In other words, they become aware of their judgement, as they continue to be curious. In this type of dialogue, participants slow down the inquiry by allowing some spaces between the speakers. Instead of prejudicial attitudes, dialogue partners speak from their own experience, which is speaking their own truth. There are three practical suggestions for church's engagement in and through Difficult Dialogue.

Difficult Dialogue is an opportunity for people to encounter each other in dignity with a goal of building a sane human community. South Africans of all races were racially marginalised and balkanised and therefore they do not know each other as they should. In the democratic dispensation, efforts are made to break all the barriers of hostilities, especially so for Christians who claim the same confession and dogma. It is ideally recommended in this article that Difficult Dialogue be utilised for people to come closer to each other and cross these barriers to worship together as a testimony that indeed: 
Make every effort to keep the unity of the Spirit through the bond of peace. There is one body and one Spirit, just as you were called to one hope when you were called; one Lord, one faith, one baptism; one God and Father of all, who is over all and through all and in all. (Eph 4:3-6)

The dignified encounter through Difficult Dialogue ushers in the feeling of inherent value and worth, and recognition of basic human rights (Hicks 2013:6). I believe most South Africans, irrespective of race or culture, find it reasonable and acceptable 'to build human communities and justice by fostering understanding and respect for the value of all humans, especially in contexts of radical human difference' (Moore \& Kim 2018:315). Churches are encouraged for opportunities of engaging Difficult Dialogues.

\section{Change a church space into the centre of learning}

Discussions abound regarding the type of ecclesiastical environment that is most conducive for church learning. One aspect of a good pastoral and missional task is creating a church environment where dominant ideologies are challenged. This is always a daunting task because expressions of intolerance, experiences of discrimination, and human inability to embrace those different from us, have plagued South Africa for centuries (Winings 2018:353). A learning church is often in a process of tension, as congregants confront social issues at a cognitive level either affectively, internally or externally. One strategy for managing these discussions involves creating safe spaces for Difficult Dialogues, or emotional exchanges. A safe place requires physical safety, a learning environment free from violence that allows educational experiences. Beyond physical violence and verbal threats, a safe place can refer to inclusive groups of learners, students who may be underrepresented based upon race, sexuality, religion, nationality or ideology (Gayle, Cortez \& Preiss 2013:3).

Taking from the colonial culture, the church in South Africa has always been regarded as a holy space to be treated with extreme and cautious respect. The church has become a sacred space secluded from intrusion. The sanctity of such space determines this seclusion (Ngozi 2016:1). It is for this reason that driving around some former South African white suburbs, one would see road signals: 'Stilte Kerk/Silence Church'. The church environment is so sacred that nothing loud or 'unholy' should be expected around it. Many church buildings received fresh air on Sundays as they were closed or even locked during the week. Vivacity was visible around the church only on Sunday. The church was and still is a place of better clothes, hence the ardent statement that a person who is smartly dressed, is referred to as in his or her Sunday's best. This led into a bad culture that consistently undermine an amazing mission, vision and strategy of the church. With Difficult Dialogue as a tool towards mutual understanding, the church should become a centre of learning, a place where people become transparent with each other and talk their inhibitions out. The role of the church must scaffold from only vertical relationships to also horizontal relationships. The biblical teaching is very clear in 1 John 4:19-21:
We love because he first loved us. Whoever claims to love God yet hates a brother or sister is a liar. For whoever does not love their brother and sister, whom they have seen, cannot love God, whom they have not seen. And he has given us this command: Anyone who loves God must also love their brother and sister.

The church should be a space of mutual acceptance and respect. It is where people, regardless of their differences of emphasis, desires, subject, abilities, weaknesses and sins, are welcome by the trinitarian God and therefore a place where they get involved in a joint and common calling. The church should be a safe space leading to openness. It is where members have the freedom to make mistakes within the safety of the group, to voice their views and even struggle on difficult issues which divide Christians. It is a space to disagree regarding the vision, but with an acknowledgement of accountability to Christ and church leadership structures.

The church is a space where love rules the relationships. There is bound to be tension at times within a church, but the basic rules of Christian love - preferring the other, self-sacrifice, acts of love, make a vast contribution to peace and effectiveness. This space possesses a sharp intellectual freedom where each member challenges and sparks the other into deeper and wider thought. Difficult Dialogue often develops an enabling and prophetic space for the churches and society to co-exist for the benefit of life at large. Churches struggle to cope with the stream of new ideas and attitudes occurring in society, from postmodernity to debate over the latest medical procedures, legal decisions or films. The church is best placed to guide the nation's thinking and speak on these issues - and should be encouraged to do so as a prophetic voice to fulfil Christ's mandate as a peacemaker in the world. Quietness in times of crises is equal to participation as perpetrator of the crises. The church as the redeemed company communing with Christ, should become or offer solution through dialogues with the world systems that may be threatening the dignity of humanity and the demands of justice.

\section{Utilise people's stories}

One of the powerful tools that can be utilised in bringing people into self-understanding, is personal stories. For many victims of repressive ideologies such as apartheid, childhood questions about the importance, worth and beauty attached to being black, are still looming in their minds. The police brutality, restriction of movements, white supremacist ideals of treating black people as trash, still hang in their memories. Their white counterparts are still taken aback realising how evil happened right under their noses, but they could not see it.

In the predominantly white public service, the reminder of their subjugation came in the form of education with limited governmental support. The services such as health services, access to basic needs such as water, electricity, et cetera were not extended to them, as they were treated as sub-humans. Sports, arts and cultural events were not given support by the minority white government. Wimberly, an African American educationist in her famous book 
(Wimberly \& Farmer 2017), Raising hope: Four paths to courageous living, reiterates her situation that was similarly to the South African situation that:

Outside school, the truth was that family resources were meagre. Healthcare was non-existent. But, where prejudice prevailed, life's prospects seemed blocked, and scant economic means held sway, my family and faith community together served as affirming and empowering agents of hope, engendering trust in God's for-us-ness and the ability of young people to both survive and thrive. (p. viii)

This teaches one that affirmation comes from one's rightful presence in the human family with a voice, gifts and graces to build the beloved community against and even notwithstanding opposition. Importantly, in the throes of life's toughness, the family and 'village' possesses the capacity of belief in the God who sees their sorrow and hear their lament. People should be afforded personal freedom to be in conversation with God and to share their thoughts to those who would listen. The power of the personal story lies in the fact that people are led to tell and retell their stories in such a way that reinterpretation and reconstruction can eventually happen (Buqa 2015:2).

The authentic worshiping community creates a space for personal testimonies, sharing specifically chosen happenings in everyday life, meanings of those stories, and God's activity in them. Invariably filled with emotion, personal testimony reveals turning points in the personal life of the testifier. Hoyt (2010:89-102) is quite right in his assertion that 'In testimony, people speak truthfully about what they have experienced and see, offering it to the community for the edification of all.'

A story is not seen only as a means of releasing information, but also as a means to come to yourself (Muller 1999:2). Personal story sharing enhances experiences and empowers passive listeners who may feel victimised to open-up and take charge in sharing their own personal journeys. Personal experiences and stories emphasise awareness of historically marginalised black people and therefore creates a place and a process to share their stories. They envision a way forward in life amid a climate of upheaval, racial division, and a sense of hopelessness, lovelessness and powerlessness. The white communities also need to share their stories. Dialogue is a very important tool as stresses by Johnson 2018:

Dialogue is a matter more of listening than of speaking. Behind every belief or stance is a story; and behind every story there is a person. It is possible to disagree with another person's position, but not with their livid experience. You can win a debate, but not a dialogue. (p. 283)

The themes of faith and hope are the centres of theological outlook in the believer's life. 'We inhabit the great stories of our culture. We live through stories. We are lived by the stories of our race and place' (Freedman \& Combs 1996:32). Stories told by both victims and those who were on the side of the oppressors, lead to change in behaviours, and they model significance and worth of individuals due to their content of confession, which is a powerful tool of emotional and spiritual liberation. Ntombana and Bubulu (2017:3) are correct that, through interactions with others, previously held beliefs, knowledge, understandings and values become destabilised. In the same vein, Wimberly, in another book she wrote with Farmer (Wimbley \& Farmer 2017), points out that the lives, stories and sayings of adults from the era of enslavement and thereafter, reveal that:

Living in faith and hope constitutes a dynamic mode of being in the world that opposes the languid and life-defying mind-frame of hopelessness, purposelessness, and lovelessness. ... Faith is understood as our belief or trust in our relationship with God and Gods relationship with us. ... Hope is our expectation and Endeavours to live confidently and courageously in community after the model of Jesus in times of triumph and in the midst of hard trials and tribulations. (p. xiv)

\section{Church culture should reflect multiculturalism and diversity}

Apartheid has made South Africans convinced churches to prefer their mono-cultural experience, hence resisting change. Yet, change is coming. From the researchers and theologians' point of view, the motivation for multiculturalism must be theological. The Bible's storyline from Babel (Gn 11) to Pentecost (Ac 2) insists that the new community of believers should strive for diversity. Multiculturalism should not be accepted, but rather sought after. Multicultural churches are therefore not a mere mix of different ethnicities; they truly embrace various cultures. There is no doubt that dialogical personal encounters lead to more intense talks about dialogue partners' inhibitions. 'When we speak about what really matters to us, this creates inner personal bonds with others' (Gabriel 2017:318).

Multicultural component is not just when people of various ethnic groups listen to the same music, eat the same foods, hang out at the same entertainment venues, and go to church together. They have assimilated to a common culture. It may be multi-ethnic, but it is still mono-cultural. Churches of this type are found in many, if not all historically white suburbs, but especially in the upmarket areas such as Sandton in Johannesburg, Constantia in Cape Town, et cetera. A multicultural church will not simply have black people, but will engage to some degree in African or black cultural contexts.

Multiculturalism and diversity should be reflected in membership composition and the leadership of the church. A truly multicultural congregation in South Africa is one in which the membership and leadership are multiracial, multi-ethnic, and share power and influence over the church's governance, worship, theology and doctrine, and programming. The leadership is intentional to shape its preaching, teaching and worship on a regular basis. These intentions expose members to theological views and worship styles from different cultural backgrounds. A truly multicultural congregation recognises that not one cultural group has a complete understanding of God's kingdom, and 
that everyone benefits when they embrace and learn from different groups' views of the Trinitarian and transcendent God. The multicultural congregation creates a platform for everyone to learn to be teachable and understand other cultures.

\section{Conclusion}

Multiculturalism is inevitable in South Africa. It is happening in jobs and learning spaces, but still finding it difficult in religious spaces. However, it is coming slowly, despite the racial divisions of the past still dominating denominational structures and polities. Intervention programmes such as Difficult Dialogue can be used and applied in churches to foster relationships and understanding of each other. Christianity is a vocal faith. It expresses itself verbally in liturgy, confessions, kerygmatic tasks, diaconal initiatives, didactical duties and dogmatic expressions. Christians are a communion that is in dialogue with God and with each other. As a result, this dialogue brings a better understanding of each other. It also enhances civic harmony and cooperation, for when the church is civilly aligned, the community becomes peaceful. Johnson (2018) states:

In civic perspective, dialogue across divides is engaged to promote mutual understanding and civility as goals, while in religious perspective, dialogue across differences is often seen theologically as a means of practicing reconciliation and hospitality. The latter are indeed indispensable ecclesial practices. (p. 10)

The goal of Difficult Dialogue in a church is to create an inclusive and effective learning environment in which opportunities for complex cognitive, intrapersonal and interpersonal development exists for church members. ${ }^{1}$ This kind of church develops structures and atmospheres that promote dialogue, inclusion and respect. The safe space is a platform for designing churches that address difficult or tension-filled religious encounters. Church members flourish and feel empowered to freely share their unique insights and differ with fellow members with understanding and love. A safe space does not guarantee that worshippers will grapple with opposing views or interrogate perspectives through the Difficult Dialogue but facilitates a smooth way towards interacting relationships. Safety alone is not enough to promote a deep understanding of each other. Difficult Dialogue increases this understanding as communication starts to flow towards understanding each other. Resane (2017) opines:

Dialogue makes participants more sympathetic to one another, even when they disagree, and assists enormously in preparing the ground for negotiation or decision-making on emotion-laden issues. (p. 204)

Feelings start to roll out as church members engage in dialogue with each other. Although topics of Difficult Dialogues tend to be sensitive, the more they are engaged, the lesser their sensitiveness. The bottom line is 'dialogue minimizes prejudice, stereotypes, bigotries and inhibitions' (Resane 2019b:301).

1.See https://digitalcommons.georgiasouthern.edu/cgi/viewcontent.cgi?article=1390= ij-sotl.

\section{Acknowledgements Competing interest}

The author declares that there is no competing interest.

\section{Author's contributions}

I declare that I am the sole author of this research article.

\section{Ethical consideration}

This article followed all ethical standards for carrying out research without direct contact with human or animal subjects.

\section{Funding information}

This research received no specific grant from any funding agency in the public, commercial or not-for-profit sectors.

\section{Data availability statement}

Data sharing is not applicable to this article as no new data were created or analysed in this study.

\section{Disclaimer}

The views and opinions expressed in this article are those of the author and do not necessarily reflect the official policy or position of any affiliated agency of the author.

\section{References}

Buqa, W., 2015, 'Storying Ubuntu as a rainbow nation', Verbum et Ecclesia 36(2), Art. \#1434, 8 pages. https://doi.org/10.4102/ve.v36i2.1434

Clapp, R., 1996, A peculiar people: The church as culture in a Post-Christian Society, InterVarsity, Downers Grove, IL.

Emerson, M., 2000, Divided by faith: Evangelical religion and the problem of race in America, Oxford University Press, Oxford.

Fears, B.A., 2017, 'Freedom train: The underground railroad as a model of Christian education, antiracism, and Human Rights advocacy', Religious Education 112(1), 19-32. https://doi.org/10.1080/00344087.2016.1256366

Francis, J.E., 2019, 'Integrating resilience, reciprocating social relationships, and Christian formation', Religious Education 114(4), 500-512. https://doi.org/10.108 0/00344087.2019.1631948

Freedman, J. \& Combs, G., 1996, Narrative therapy: The social construction of preferred realities, Norton, New York, NY.

Gabriel, I., 2017, 'All life is encounter: Reflections on interreligious dialogue and concrete initiatives', Religious Education 112(4), 317-322. https://doi.org/10.108 $0 / 00344087.2017 .1325096$

Gayle, B.M., Cortez, D. \& Preiss, R.W., 2013, 'Safe spaces, difficult dialogues, and critical thinking', International Journal for the Scholarship of Teaching and Learning 7(2), https://doi.org/10.20429/ijsotl.2013.070205

Hicks, D., 2013, Dignity: Its essential role in in resolving conflict, Yale University, Cape Town.

Hoyt, Jr. T., 2010, Testimony: In practicing our faith, ed. D.C. Bass, 2nd edn., pp. 89-102, Wiley, San Francisco, CA.

Johnson, S., 2018, 'Speaking together differently to live together differently: The promise of the public dialogue movement', Religious Education 113(3), 277-288. https://doi.org/10.1080/00344087.2018.1455568

Kanpol, B. \& McLaren, P. (eds.), 1995, Critical multiculturalism: Uncommon voices in a common struggle, Bergin \& Garvey, Westport, CT.

Moon, D., 2013, 'Difficult dialogues: The technologies and limits of reconciliation', in C. Bender, W. Cadge, P. Levitt \& D. Smilde (eds.), Religion on the edge: De-centering and re-centering the sociology of religion, pp. 179-199, Oxford University Press, Oxford.

Moore, M.E. \& Kim, S.M., 2018, 'Encountering dignity: Building human community', Religious Education 113(3), 314-325. https://doi.org/10.1080/00344087.2018.14 56068

Muller, J.C., 1999, Companions on the journey, Logos Electronic Publishers, Johannesburg.

Ngozi, E., 2016, 'Sacred space: A comparative study of Awka Traditional Shrines', Pharos Journal of Theology 97, viewed 26 October 2019, from http//:www. pharosjot.com. 
Ntombana, L. \& Bubulu, T., 2017, 'Shifting boundaries of racial space in post-apartheid South Africa: The case of Afrikaner youth in East London', The Journal for South Africa: The case of Afrikaner youth in East London, The Journal for
Transdisciplinary Research in Southern Africa 13(1), a432. https://doi. org/10.4102/td.v13i1.432

Resane, K.T., 2017, Communion ecclesiology in a racially polarised South Africa, Sun Media, Bloemfontein.

Resane, K.T., 2019a, 'Hybridity, diaspora, and missio Dei', The South African Baptist Journal of Theology 28, 15-31.

Resane, K.T., 2019b, 'Theology of dialogue in peace negotiations and settlement: A South African case', Stellenbosch Theological Journal 5(1), 299-316. https://doi. org/10.17570/stj.2019.v5n1.a14
Shorter, A., 1991, The church in the African city, Geoffrey Chapman - An Imprint of Cassell Publishers, London.

Sue, D.W., 2015, Race talk and the conspiracy of silence: Understanding and facilitating difficult dialogue on race, Wiley, San Francisco, CA.

Wimberly, A.E.S., 2010, Nurturing faith \& hope: Black worship as model for Christian Education, p. viii, Wipf \& Stock, Eugene, OR.

Wimberly, A.E.S. \& Farmer, S.F., 2017, Raising hope: Four paths to courageous living, p. xiv, New Room Books, Nashville, TN.

Winings, K., 2018, 'White normativity: Will wisdom come?', Religious Education 113(4),353-357. https://doi.org/10.1080/00344087.2018.1491752 